\title{
Editors and contributors
}

\section{EDITORS}

Martin Scheinin is Professor of International Law and Human Rights at the European University Institute and former United Nations Special Rapporteur on human rights and counter-terrorism

Helle Krunke is Professor of Constitutional Law, Head of Centre for Comparative and European Constitutional Studies, Faculty of Law, University of Copenhagen

Marina Aksenova is Postdoctoral Research Fellow at iCourts, Centre of Excellence for International Courts, Faculty of Law, University of Copenhagen

\section{CONTRIBUTORS}

Antoni Abat i Ninet is Professor of Comparative Constitutional Law, Centre for Comparative and European Constitutional Studies, Faculty of Law, University of Copenhagen

Ebrahim Afsah is Associate Professor of Public International Law, Centre for Comparative and European Constitutional Studies, Faculty of Law, University of Copenhagen

Carlos Ayala is Professor of Constitutional Law and Head of Department at Universidad Católica Andrés Bello (Venezuela) and former President of the Inter-American Commission of Human Rights

Aharon Barak is Professor of Law at the Interdisciplinary Center in Herzliya and a lecturer in law at the Hebrew University of Jerusalem, the Yale Law School, Georgetown University Law Center, and the University of Toronto Faculty of Law, and former Chief Justice of the Supreme Court of Israel

Or Bassok is postdoctoral Max Weber Fellow at the European University Institute 
David Thór Björgvinsson is Professor at iCourts, Centre of Excellence for International Courts, Faculty of Law, University of Copenhagen and former Judge of the European Court of Human Rights

Wolfgang Hoffmann-Riem is Professor at the University of Hamburg and former Judge of the Federal Constitutional Court of Germany

David Hope (The Lord Hope of Craighead) is former Deputy President of the Supreme Court of the United Kingdom

David Jenkins is Associate Professor of Comparative Constitutional Law, Centre for Comparative and European Constitutional Studies, Faculty of Law, University of Copenhagen

TJ McIntyre is Lecturer in Law at the University College Dublin Sutherland School of Law and Chairperson of Digital Rights Ireland

Bakhtiyar Tuzmukhamedov is Professor of International Law at the Diplomatic Academy in Moscow, Vice President of the Russian Association of International Law and Judge at the International Criminal Tribunal for the Former Yugoslavia

Geir Ulfstein is Professor at the Department of Public and International Law, University of Oslo

Anita Ušacka is former Judge of the International Criminal Court and former Judge of the Constitutional Court of the Republic of Latvia 